\title{
The Status of Neuroendocrine Tumor Imaging: From Darkness to Light?
}

\author{
Lisa Bodei $^{\mathrm{a}} \quad$ Anders Sundin $^{\mathrm{b}}$ Mark Kidd ${ }^{\mathrm{c}}$ Vikas Prasad $^{\mathrm{d}}$ Irvin M. Modlin ${ }^{\mathrm{c}}$ \\ ${ }^{a}$ Division of Nuclear Medicine, European Institute of Oncology, Milan, Italy; ${ }^{b}$ Department of Radiology, Section \\ for Molecular Imaging, Uppsala University Hospital, Uppsala, Sweden; ' Department of Gastroenterological \\ Surgery, Yale University School of Medicine, New Haven, Conn., USA; ${ }^{d}$ Department of Nuclear Medicine, \\ Campus Virchow-Klinikum, Charité University Hospital, Berlin, Germany
}

\begin{abstract}
Key Words
Neuroendocrine tumors · Imaging $\cdot$ Computed

tomography $\cdot$ Magnetic resonance imaging $\cdot$ Scintigraphy

Positron emission tomography
\end{abstract}

\begin{abstract}
Diagnostic imaging plays a pivotal role in the diagnosis, staging, treatment selection and follow-up for neuroendocrine tumors. The available diagnostic strategies are morphologic imaging, including computed tomography, magnetic resonance imaging (MRI) and ultrasound techniques, and molecular imaging, including scintigraphy with ${ }^{111} \mathrm{In}$ pentetreotide and positron emission tomography with ${ }^{68} \mathrm{Ga}$ DOTA-peptides, ${ }^{18} \mathrm{~F}$-DOPA and ${ }^{11} \mathrm{C}-5$-HTP. A combination of anatomic and functional techniques is routinely performed to optimize sensitivity and specificity. The introduction of diffusion-weighted MRI and dynamic contrast-enhanced techniques represents a promising advance in radiologic imaging, whereas new receptor-binding peptides, including somatostatin agonists and antagonists, represent the recent most favorable innovation in molecular imaging. Future development includes the short-term validation of these techniques, but in extension also a more comprehensive multilevel integration of biologic information pertaining to a specific tumor and patient, possibly encompassing genomic considerations, currently evolving as a new entity denoted 'precision medicine'. The ideal is a diagnostic sequence that
\end{abstract}

captures the global status of an individual's tumor and encompasses a multidimensional characterization of tumor location, metabolic performance and target identification. To date, advances in imagery have focused on increasing resolution, discrimination and functional characterization. In the future, the fusion of imagery with the parallel analysis of biological and genomic information has the potential to considerably amplify diagnosis.

(c) 2015 S. Karger AG, Basel

\section{Introduction}

Neuroendocrine tumors (NETs) represent a considerable diagnostic challenge as their clinical presentation is protean, nonspecific and usually late, often when hepatic metastases are already evident [1]. In their diagnostic workup, two critical issues are present: firstly, the need to identify tumor presence and, secondly, to define the primary location and assess regional and distant metastases. Plasma biomarkers and imaging have been used to define these areas. This includes molecular imaging techniques to acquire information on the tumor's somatostatin receptor (SSR) expression [SSR scintigraphy (SRS)] and metabolic status [ ${ }^{18}$ fluorodeoxyglucose-positron emission tomography $\left.\left({ }^{18} \mathrm{FDG}-\mathrm{PET}\right)\right]$ and histopathological examination of tumor biopsies, including immunohistochemistry, providing further information,

\section{KARGER 125}

(c) 2015 S. Karger AG, Base

0028-3835/15/1011-0001\$39.50/0

E-Mail karger@karger.com

www.karger.com/nen
Irvin M. Modlin, MD, PhD, DSc, FRCS, Emeritus Prof

Yale University School of Medicine

333 Cedar Street, PO Box 208062

New Haven, CT 06510 (USA)

E-Mail imodlin@optonline.net 
Fig. 1. Venn diagram of modalities involved in the identification of a NET. ${ }^{111}$ InOCT $={ }^{111}$ In-pentetreotide scintigraphy; ${ }^{68} \mathrm{Ga}$-PET $=$ PET with ${ }^{68} \mathrm{Ga}$-DOTA-peptides; ${ }^{18} \mathrm{~F}$-DOPA $={ }^{18} \mathrm{~F}$-dihydroxyphenylalanine; ${ }^{11} \mathrm{C}$-5-HTP $={ }^{11} \mathrm{C}$-5-hydroxy-L-tryptophan; FNA = fine-needle aspiration; FNB = fine-needle biopsy; CTC = circulating tumor cells.

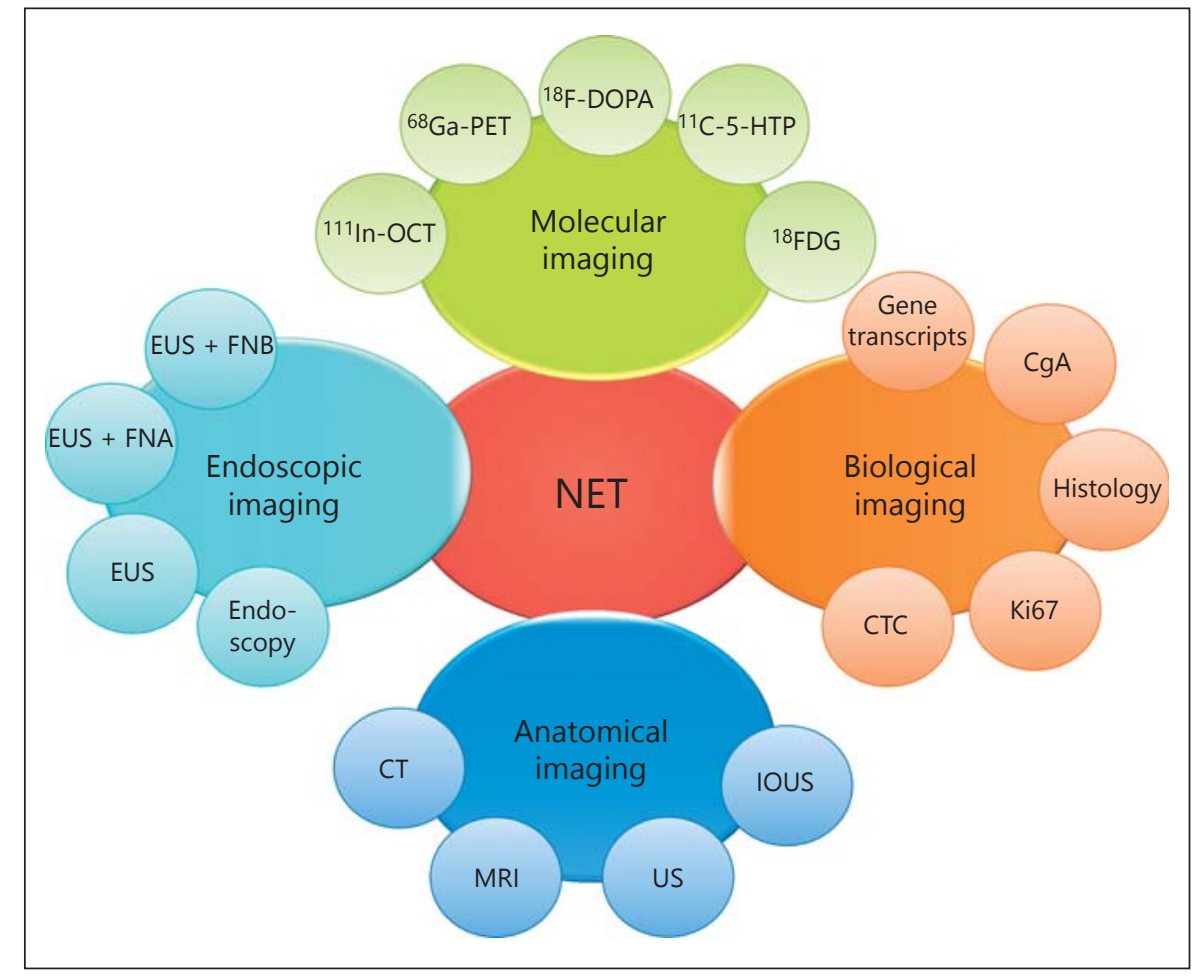

for example, on its proliferative activity (Ki67). Current biomarkers such as chromogranin- $\mathrm{A}(\mathrm{CgA})$ and 5-hydroxyindoleacetic acid (5-HIAA) are, however, generally accepted as suboptimal in terms of sensitivity and specificity [2]. The recent demonstration of specific NET transcripts in whole blood suggests that this strategy may enable early diagnosis and detection of lesions and may provide a basis for prognostic determination and therapeutic recommendation [3]. The currently evolving research area denoted 'precision medicine', by which, for example, correlations between genomics and image findings may be established, is resource demanding but holds great potential.

Imaging plays a pivotal role in diagnosis, staging, treatment selection and follow-up of NETs (fig. 1). Current diagnostic methods include morphologic modalities such as computed tomography (CT), magnetic resonance imaging (MRI), transabdominal ultrasound (US), endoscopic US (EUS) and intraoperative US (IOUS). Nuclear medicine imaging or molecular imaging consists of scintigraphy including single photon emission computed tomography (SPECT) with ${ }^{111}$ In-pentetreotide or, more recently, PET with ${ }^{68} \mathrm{Ga}$-labeled somatostatin analogs (SSA), ${ }^{18} \mathrm{~F}-\mathrm{DOPA}$ and ${ }^{11} \mathrm{C}-5$-HTP [1]. Because of the large variability between NETs in, for instance, proliferation rate (Ki67) and SSR subtype profile, no modality alone is entirely effective and, overall, these exhibit a sensitivity and specificity of $\sim 80-90 \%$ [4] (fig. 2). A combination of anatomic and functional techniques is routinely performed to optimize sensitivity and specificity and thereby maximize the acquisition of clinically relevant information $[5,6]$. This has been facilitated by the development of current hybrid scanners (SPECT/CT and PET/CT), whereby functional image findings may be directly correlated to morphology and vice versa. In disseminated disease, the tumor's SSR status is generally assessed by ${ }^{111} \mathrm{In}$-pentetreotide scintigraphy or ${ }^{68} \mathrm{Ga}-\mathrm{SSA}-\mathrm{PET} / \mathrm{CT}$ in order to also evaluate the patient's eligibility for peptide receptor radionuclide therapy (PRRT). This assessment was previously a prerequisite, also before starting systemic treatment with unlabeled SSA, but this routine has during the last few years been questioned.

The major unmet need in NET imaging is, however, the development of more inclusive criteria for therapy monitoring that apply to slow-growing tumors and allow the validation of the more recent functional techniques (MRI and PET) as well as integrate biologic and metabolic information (table 1) [3,7]. This article assesses the strengths and limitations of current imaging approaches for NETs and describes the future perspectives using a SWOT analysis structure. 
Fig. 2. Methods for the identification of primary and metastatic gastroenteropancreatic NETs. Data are pooled from 52 studies and are mean (95\% confidence interval). Data for specificity and sensitivity are not comparable across studies. $\mathrm{S}=\mathrm{Cal}-$ culated sensitivity.

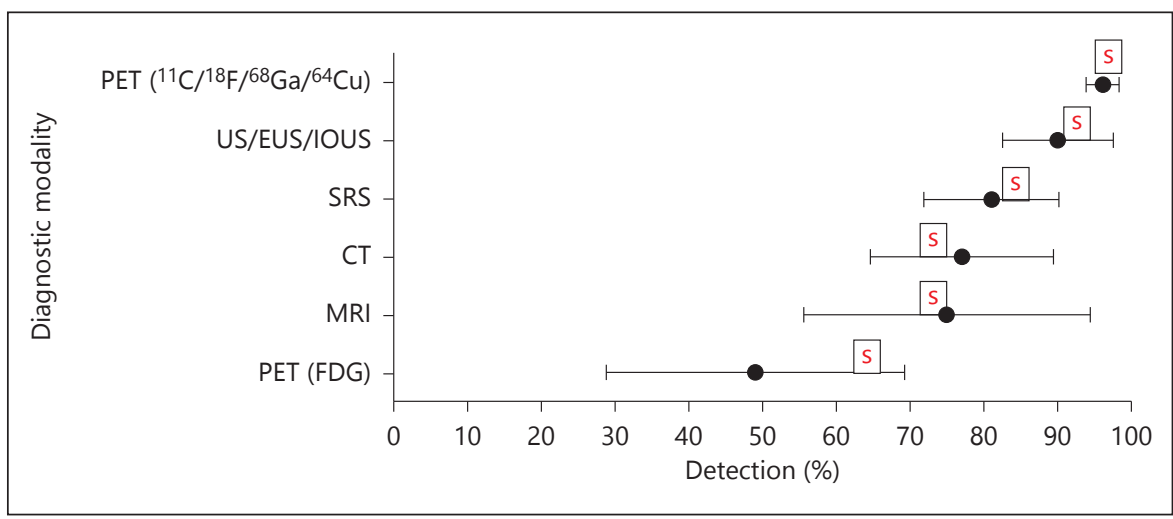

Table 1. The role of morphologic and molecular imaging techniques in NETs

\begin{tabular}{|c|c|c|c|c|c|c|}
\hline & Primary & Localization & Staging & Restaging & Therapy selection & $\begin{array}{l}\text { Modification of } \\
\text { management }\end{array}$ \\
\hline \multirow[t]{7}{*}{ GEP } & $\begin{array}{l}\text { Pancreas } \\
{\text { (functional })^{\mathrm{a}}}\end{array}$ & $\begin{array}{l}\text { SRI }[21,47,114,115] \\
\text { EUS }[1,8] \\
\text { CT/MRI }[8,116] \\
{ }^{11} \text { C-5-HTP }[26]\end{array}$ & $\begin{array}{l}\text { SRI + CT/MRI }[5,6] \\
{ }^{11} \mathrm{C}-5-\mathrm{HTP}[26]\end{array}$ & $\begin{array}{l}\text { SRI + CT/MRI }[5,6] \\
{ }^{11} \mathrm{C}-5-\mathrm{HTP}[26]\end{array}$ & $\begin{array}{l}\text { SRI: SSA, PRRT [48] } \\
\text { CT/MRI: surgery [1] }\end{array}$ & $\begin{array}{l}\text { SRI }[47,57] \\
\text { FDG }[29]\end{array}$ \\
\hline & $\begin{array}{l}\text { Pancreas } \\
\text { (nonfunctional) }\end{array}$ & $\begin{array}{l}\text { EUS }[1,8] \\
\text { SRI }[17,21,115,117] \\
\text { CT/MRI }[8,116]\end{array}$ & $\begin{array}{l}\text { SRI + CT/MRI }[5,6] \\
{ }^{11} \mathrm{C}-5-\mathrm{HTP}[26]\end{array}$ & $\begin{array}{l}\text { SRI + CT/MRI }[5,6] \\
{ }^{11} \mathrm{C}-5-\mathrm{HTP}[26]\end{array}$ & $\begin{array}{l}\text { SRI: SSA, PRRT [48] } \\
\text { CT/MRI: surgery [1] }\end{array}$ & $\begin{array}{l}\text { SRI }[47,57] \\
\text { FDG }[29]\end{array}$ \\
\hline & Duodenum & $\begin{array}{l}\text { SRI }[21,114,115] \\
\text { EUS [1] }\end{array}$ & $\begin{array}{l}\text { SRI + CT/MRI }[5,6] \\
{ }^{11} \mathrm{C}-5-\mathrm{HTP}[26]\end{array}$ & $\begin{array}{l}\text { SRI + CT/MRI }[5,6] \\
{ }^{11} \mathrm{C}-5-\mathrm{HTP}[26]\end{array}$ & $\begin{array}{l}\text { SRI: SSA, PRRT [48] } \\
\text { CT/MRI: surgery [1] }\end{array}$ & $\begin{array}{l}\text { SRI }[47,57] \\
\text { FDG }[29]\end{array}$ \\
\hline & Small bowel & $\begin{array}{l}\text { SRI }[17,117-119] \\
\text { video-capsule } \\
\text { DB enteroscopy [120] } \\
\text { CT [8] }\end{array}$ & $\begin{array}{l}\text { SRI + CT/MRI }[5,6] \\
{ }^{18} \text { F-DOPA }[58]\end{array}$ & $\begin{array}{l}\text { SRI + CT/MRI }[5,6] \\
{ }^{18} \text { F-DOPA }[58]\end{array}$ & $\begin{array}{l}\text { SRI: SSA, PRRT [48] } \\
\text { CT/MRI: surgery [1] }\end{array}$ & $\begin{array}{l}\text { SRI [117] } \\
\text { FDG [29] }\end{array}$ \\
\hline & Gastric & $\begin{array}{l}\text { EUS [8] } \\
\text { SRI [121] } \\
\text { CT [121] }\end{array}$ & SRI + CT/MRI $[5,6]$ & SRI + CT/MRI $[5,6]$ & $\begin{array}{l}\text { SRI: SSA, PRRT [48] } \\
\text { Endoscopy: resection } \\
{[121]}\end{array}$ & \\
\hline & Colon & $\begin{array}{l}\text { EUS [8] } \\
\text { SRI [121] } \\
\text { CT [121] }\end{array}$ & SRI + CT/MRI $[5,6]$ & SRI + CT/MRI $[5,6]$ & $\begin{array}{l}\text { Endoscopy: } \\
\text { resection [121] } \\
\text { SRI: SSA, PRRT [48] } \\
\text { CT: surgery [1] }\end{array}$ & $\begin{array}{l}\text { SRI [57] } \\
\text { FDG [29] }\end{array}$ \\
\hline & Rectum & $\begin{array}{l}\text { EUS [8] } \\
\text { SRI [121] } \\
\text { CT/MRI }\end{array}$ & $\mathrm{SRI}+\mathrm{CT} / \mathrm{MRI}[5,6]$ & SRI + CT/MRI $[5,6]$ & $\begin{array}{l}\text { SRI: SSA, PRRT [48] } \\
\text { CT: surgery [1] } \\
\text { Endoscopy: resection [1] }\end{array}$ & $\begin{array}{l}\text { SRI [57] } \\
\text { FDG [29] }\end{array}$ \\
\hline Bronchial & Bronchia & $\begin{array}{l}\text { Bronchoscopy [120] } \\
\text { SRI [122] }\end{array}$ & $\begin{array}{l}\text { SRI [123] } \\
\text { CT [123] } \\
\text { FDG [124] }\end{array}$ & $\begin{array}{l}\text { SRI [123] } \\
\text { CT [123] } \\
\text { FDG [124] }\end{array}$ & $\begin{array}{l}\text { Bronchoscopy: } \\
\text { resection [120] } \\
\text { CT (MRI): surgery [123] } \\
\text { SRI: SSA, PRRT [48] }\end{array}$ & $\begin{array}{l}\text { SRI [57] } \\
\text { FDG [29] }\end{array}$ \\
\hline Unknown & Unknown & SRI [125] & SRI + CT/MRI $[5,6]$ & SRI + CT/MRI $[5,6]$ & $\begin{array}{l}\text { SRI: SSA, PRRT [48] } \\
\text { CT: surgery, locally } \\
\text { directed ablative } \\
\text { therapies [121] }\end{array}$ & $\begin{array}{l}\text { SRI [57] } \\
\text { FDG [29] }\end{array}$ \\
\hline
\end{tabular}

GEP = Gastroenteropancreatic; SRI = somatostatin receptor imaging with either ${ }^{111}$ In-pentetreotide or PET/CT with ${ }^{68} \mathrm{Ga}-\mathrm{DOTA}-\mathrm{SSA}$; DB enteroscopy $=$ double-balloon enteroscopy. ${ }^{\text {a }}$ Except for insulinoma. 


\section{Techniques}

(1) US: Transabdominal US is often the first technique utilized for NET imaging. This is simply based upon its noninvasiveness and utility. Its efficacy is, however, low. US allows for easy guidance of the biopsy needle for fineneedle aspiration cytology or core biopsy for histopathological examination. Improved techniques, including contrast-enhanced US (CEUS), EUS and IOUS have allowed for an increase in sensitivity.

(2) CT/MRI: Primary NETs are usually identified using conventional imaging with intravenously contrastenhanced CT and MRI which are also the principal methods used for the detection of the primary tumor, describing its local extent, staging of locoregional and distant metastases, as well as for the assessment of therapeutic response. Contemporary CT utilizes multidetector (MDCT) scanners, while MRI employs a field strength of at least $1.5 \mathrm{~T}$ and currently includes many signal sequences to increase tissue contrast and facilitate tissue characterization. Unless contraindicated, for instance because of impaired kidney function, both CT and MRI of the liver and pancreas should be performed as multiphasic studies before and during intravenous contrast enhancement in the late arterial (portal venous inflow) and venous (portal-venous) phases [8]. Since neuroendocrine lesions and their metastases are usually hypervascular, they enhance in the late arterial phase after contrast medium injection on CT and MRI. The variations in this aspect are large and it is fairly common also with hypovascular metastases that are best delineated in the venous contrast enhancement phase. Occasionally, the patient may harbor both hypervascular and hypovascular liver metastases. The sensitivity for pancreatic NETs ranges from 69 to $94 \%$ for CT, 74 to $94 \%$ for MRI and is $>80 \%$ for EUS coupled with biopsy [8-13]. The sensitivity for locating a primary small intestine NET is $100 \%$ for CT enteroclysis and $86-94 \%$ for MRI [14-16].

(3) Nuclear medicine imaging or molecular imaging: These techniques provide information for establishing the SSR status ( ${ }^{111}$ In-pentetreotide), metabolic activity $\left({ }^{18} \mathrm{FDG}\right)$ and specific amine or peptide regulatory profile (e.g. $\left.{ }^{18} \mathrm{~F}-\mathrm{DOPA}\right)$. In addition, they generally provide further details in respect of the extent of disease and thereby facilitate more accurate staging and precise therapy.

(a) The radiolabeled SSA ${ }^{111} \mathrm{In}$-pentetreotide is the most commonly used agent for SRS. Examination comprises two-dimensional planar imaging and three-dimensional SPECT at 4, 24 and optionally at $48 \mathrm{~h}$ after injection according to recommended protocols [17].
With the increasing use of SPECT/CT, allowing for anatomical correlation of the SPECT findings, the need for the 4- and 48-hour examinations is, however, generally low. The sensitivity of ${ }^{111}$ In-pentetreotide scintigraphy has been well documented and is generally $>75 \%$ for gastroenteropancreatic and bronchial tumors [18]. Since 2000, the approach to the molecular imaging of NETs has been revolutionized by the introduction of PET with the ${ }^{68} \mathrm{Ga}$-labeled octreotide derivatives DOTATOC, DOTATATE and DOTANOC $\left({ }^{68} \mathrm{Ga}-S S A-P E T / C T\right)[19$, 20]. The overall sensitivity of ${ }^{68} \mathrm{Ga}$-SSA-PET/CT for NETs is $>90 \%$, while the specificity ranges from 92 to $98 \%$ [21-23]. Recently, ${ }^{64} \mathrm{Cu}$-labeled SSA has also been tested for PET/CT of NETs [24].

(b) Alternative PET tracers: These include ${ }^{18} \mathrm{~F}$-DOPA, which measures neuroendocrine metabolism. This is a substrate utilized in the catecholamine synthesis pathway and is stored in the secretory granules [25]. In research centers, ${ }^{11} \mathrm{C}-5$-HTP, a serotonin precursor, which is the substrate for aromatic L-aminoacid decarboxylase, is also utilized [26]. ${ }^{18}$ FDG-PET is usually not considered a primary diagnostic tool in well-differentiated NETs because of its low sensitivity. ${ }^{18}$ FDG PET may instead be considered for imaging of high G2 NETs with Ki67 >15-20\% for which SRS and ${ }^{68} \mathrm{Ga}$-SSA-PET/CT may be unreliable [27]. ${ }^{18}$ FDG-PET is generally recommended for neuroendocrine cancer G3 tumors, although it has been reported as positive in $57 \%$ of G1 and $66 \%$ of G2 NETs [28]. In addition, the increased glucose metabolism, expressed as standardized uptake value (SUV), can provide predictive information in terms of overall survival and progressionfree survival (PFS) [29]. In particular, NETs that exhibited increased metabolic activity had a significantly lower disease control rate (100 vs. $76 \%$ ) and PFS (32 vs. 20 months) after PRRT compared to ${ }^{18}$ FDG-negative tumors [28]. Recent study has shown the possibility of a three-tier metabolic grading system based on the tumorto-background ratio of uptake of FDG as an independent prognostic marker [30].

\section{Technique Strengths}

\section{Morphologic Imaging}

Anatomic techniques are the primary imaging modalities used in the initial phase of the diagnostic workup to detect primary tumors, delineate the extent of metastatic disease, determine therapeutic strategy (particularly the margins of operability) and assess the therapeutic response (table $2 \mathrm{a}$ ). 
Table 2. Strengths of anatomic (a) and molecular imaging (b) techniques

a Anatomic imaging

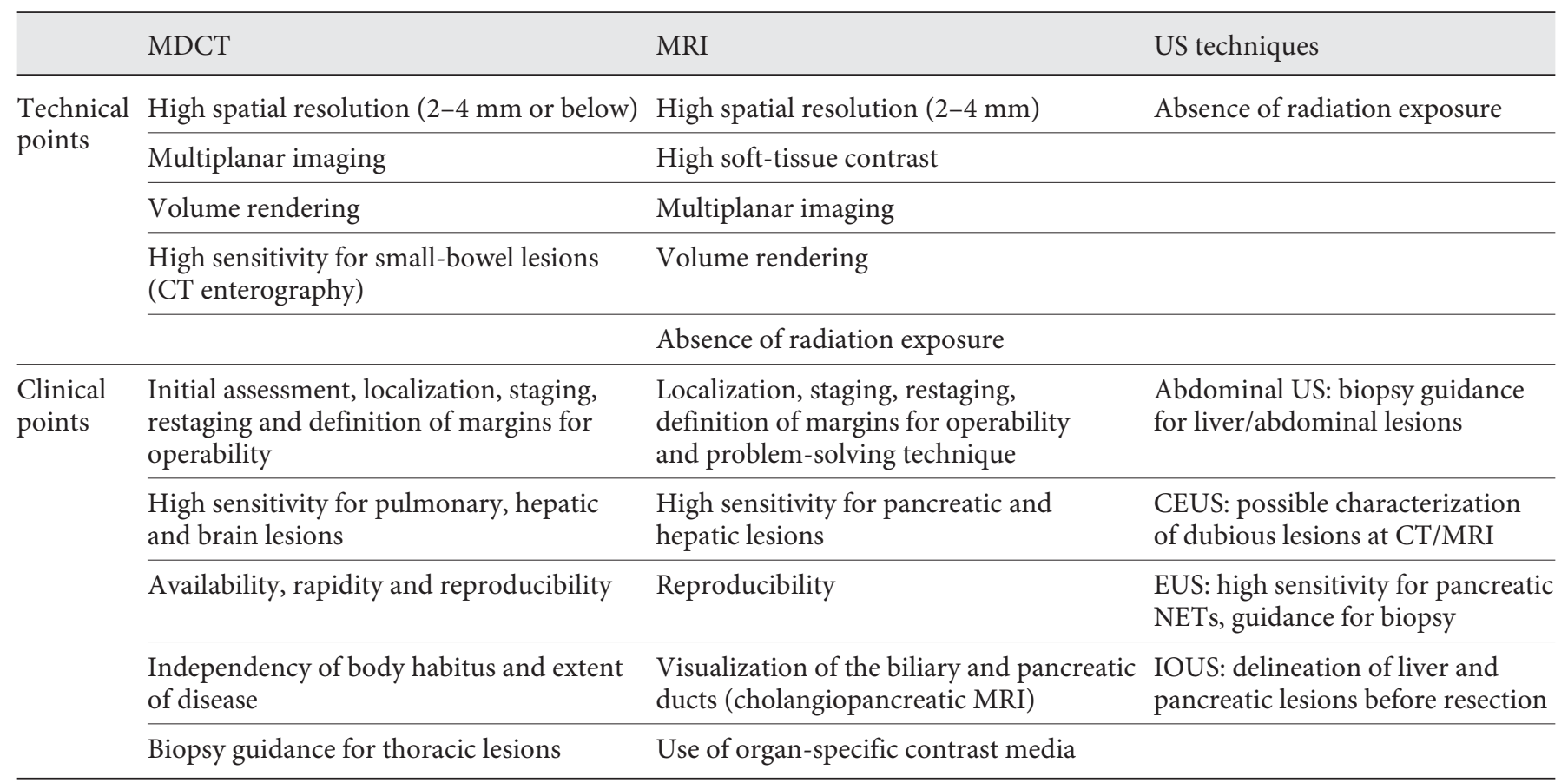

b Molecular imaging

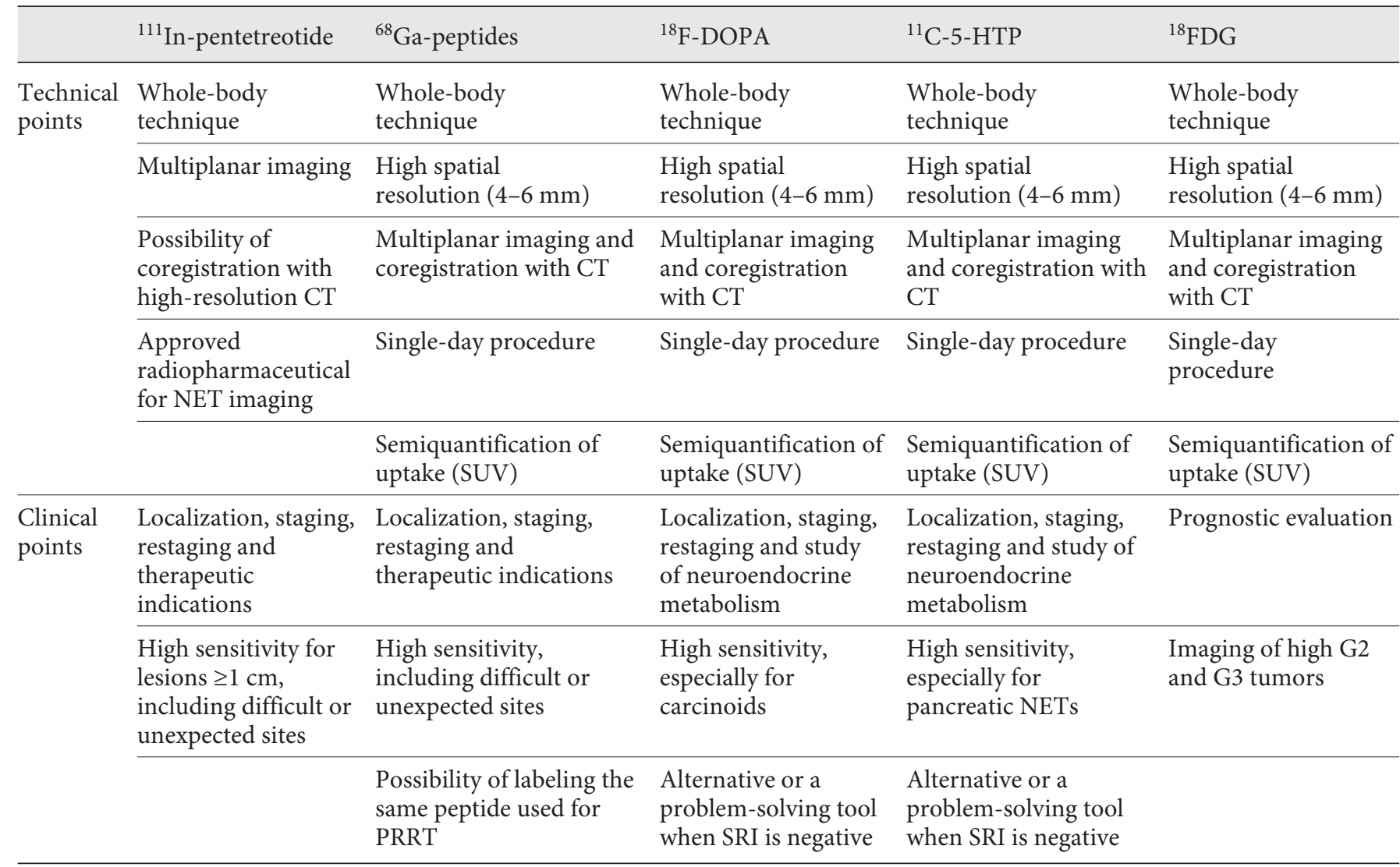


Multidetector Computed Tomography

MDCT is the standard morphologic modality for NET imaging due to its high spatial resolution, generally $<1 \mathrm{~mm}$ with recent MDCT scanners [31]. MDCT can localize the primary tumor, assess the extent of disease, characterize the architectural relationships with the surrounding structures and be used to reassess the disease following treatments $[8,32-34]$.

The multiplanarity of this technique (transaxial, coronal, sagittal and curved planes can be reconstructed) and the three-dimensional maximum intensity projection and volume rendering techniques, which delineate the organ and vascular anatomy in 3D, improve accuracy and image interpretation $[7,11,35]$. MDCT is reproducible and allows for comparison between baseline and follow-up images, irrespective of the body habitus and extent of disease. CT is the method of choice to guide the biopsy of thoracic lesions.

\section{Magnetic Resonance Imaging}

MRI has the advantage of a fairly high spatial resolution $(2-4 \mathrm{~mm})$, which is amplified by examination at a higher field strength in a 3-tesla scanner [36]. Optionally, the higher field strength may instead be utilized to shorten the acquisition time. The better soft-tissue contrast of MRI, as compared to CT, is particularly useful to detect liver metastases for which MRI represents the most sensitive technique [37, 38]. The soft-tissue contrast can be further increased by the use of liver-specific and superparamagnetic contrast media $[34,39]$. Three-dimensional acquisition allows for viewing in multiple anatomical planes to enable accurate image interpretation. In addition, the absence of radiation exposure renders MRI the technique of choice especially in the young or those with long-standing disease who require repeated assessments $[7,11,34]$.

MRI has similar indications as CT and, due to availability and costs as well as its optimal interobserver agreement, it is generally used as a problem-solving technique $[37,40]$. MRI is particularly advantageous in localizing primary pancreatic tumors and for staging and restaging liver lesions [37]. Moreover, cholangiopancreatic sequences (magnetic resonance cholangiopancreatography), directed at studying the involvement of the biliary and pancreatic ducts, are useful for surgical planning and should always precede resection of a pancreatic NET $[8,41]$.

\section{US Techniques}

US is the modality used to guide liver and other abdominal biopsies. The absence of radiation exposure makes it a highly repeatable technique. Despite the gen- erally low sensitivity among anatomic modalities in localizing NETs (13-27\%) [42, 43], improved techniques, including CEUS, EUS or IOUS, show better performance. EUS is the most advantageous modality to detect pancreatic NETs, with pooled sensitivity and specificity of 87 and $98 \%$, respectively, in a systematic review [44], and it represents a guide for fine-needle aspiration cytology or core biopsy [45]. Finally, the juxtaposition of the probe, during IOUS, facilitates the study of the liver and the pancreas [1] and is generally recommended in connection with resection of liver metastases and pancreatic NETs, especially in multiple endocrine neoplasia patients.

\section{Molecular Imaging}

Besides localization, staging and restaging of primary and metastatic tumors, molecular imaging allows for the functional characterization of lesions and the therapy selection with cold or radiolabelled SSA (PRRT). Functional imaging has a clinical impact in terms of modification of the therapeutic strategy and of prognosis (table $2 b$ ).

\section{${ }^{111}$ In-Pentetreotide}

This is the only universally approved radiopharmaceutical for NET imaging. A ${ }^{99} \mathrm{~m}$ Tc-labeled compound $\left({ }^{99 \mathrm{~m}} \mathrm{Tc}-\mathrm{EDDA} / \mathrm{HYNIC}-\mathrm{TOC}\right)$ is registered in Poland and commercially available in some European countries [46]. The use of ${ }^{111}$ In-pentetreotide to localize, stage, restage as well as provide therapeutic indications was a major advance in NET management $[5,47,48]$. An optimal protocol, including three-dimensional reconstructed SPECT images and, possibly, high-resolution CT coregistration (SPECT/CT), ensures good image quality and provides useful clinical information, as a whole body technique, and accurate image interpretation [17]. ${ }^{111}$ In-pentetreotide modifies the therapeutic strategy in up to $50 \%$ of cases $[47,49,50]$ and can predict the response to cold or radiolabeled analogues [48].

\section{${ }^{68} \mathrm{Ga}-\mathrm{SSA}-\mathrm{PET} / \mathrm{CT}$}

This provides several advantages over conventional scintigraphy. These include the simple and economical synthesis of the radiopeptide from an on-site ${ }^{68} \mathrm{Ge} /{ }^{68} \mathrm{Ga}$ generator eluate, the single-day procedure, the possibility of semiquantification of the activity in a given region of interest as the 'SUV', the higher spatial resolution with the detection of 4- to 6-mm lesions and, finally, the better dosimetry [51]. The intrinsic multiplanarity of the PET techniques and the coregistration with high-resolution 
CT produces low-dose, or preferably, diagnostic contrast-enhanced scans, with an improved accuracy and image interpretation [52].

Another advantage is the possibility of labeling and imaging the same peptide used for PRRT $[22,53] .{ }^{68} \mathrm{Ga}$ SSA-PET/CT has demonstrated a higher sensitivity than metabolic tracers, such as ${ }^{18} \mathrm{~F}$-DOPA and ${ }^{11} \mathrm{C}-5$-HTP, and is able to sensitively visualize difficult areas including bones, peritoneum, the heart or soft tissues $[54,55]$. It allows for localization, staging and restaging and provides therapeutic indications based on tumor SSR expression $[21,51,56]$. Moreover, it is able to modify the therapeutic management in $>50 \%[56,57]$.

\section{PET with ${ }^{18}$ F-DOPA}

This can be of value as an alternative or problem-solving tool when SSR imaging is negative or in assessing response to treatment [51]. The sensitivity of this method is higher for carcinoids given their propensity for amine metabolism $[58,59]$.

\section{PET with ${ }^{11} \mathrm{C}-5-\mathrm{HTP}$}

This may be an alternative or a problem-solving tool, when SSR imaging is negative. The sensitivity is higher for pancreatic NETs, as opposed to carcinoids, because there is no intracellular saturation from endogenous serotonin [58].

\section{PET with ${ }^{18}$ FDG}

${ }^{18} \mathrm{FDG}$ is able to define prognosis in well-differentiated tumors given their low glucose substrate activity [29] and can, therefore, predict a response to PRRT [28]. It is the method of choice over ${ }^{68} \mathrm{Ga}$-SSA-PET/CT in the identification and assessment of poorly differentiated G3 tumors, given their lower SSR expression [60].

\section{Technique Limitations}

\section{Morphologic Imaging (table 3a)}

\section{Multidetector Computed Tomography}

As assessment of hypervascular metastases, especially in the liver, is critically dependent upon the exact contrast enhancement phase and contrast medium dosage, additional difficulties, therefore, exist for reproducibility, which highlights the need for fully standardized guidelines and that these are implemented in the clinical routine [8]. Poorly demarcated large-volume liver disease is generally difficult to evaluate due to coalescence phenomena, which impede distinct margin recognition, thereby limiting the possibility of response assessment using RECIST. Other limitations include the difficulty in clear identification of small lesions, especially small lymph nodes, peritoneal lesions and bone metastases. For small lymph nodes, even when they are depicted, the conventional size criteria are of very limited value to differ benign from metastatic lesions.

An important limitation with pure morphologic techniques such as MDCT is the risk of the underestimation of therapeutic response as defined by RECIST or SWOG response criteria. This reflects two issues, namely the latency period required for slow-growing tumors to shrink and the possibility of tumor necrosis, fibrosis or hemorrhage obscuring a decrease in tumor size [34]. A further limitation is the different response criteria that have been designated as a different volumetric 'demand' to define progression: a $40 \%$ volume increase for SWOG/WHO criteria versus a $73 \%$ volume increase for RECIST. This discrepancy may generate misperceptions in comparisons of 'accuracy' [61]. This limitation was recently outlined in the interpretation of the differential antiproliferative efficacy of lanreotide and octreotide in gastroenteropancreatic NETs. The discrepant results in these two different randomized trials which assessed the antiproliferative effects of lanreotide and octreotide should be regarded in view of the different definition of PFS used by each of the groups. The bidimensional nature of the WHO assessment employed in the octreotide study implied a lower tumor burden to define progression. This would have resulted in a shorter PFS and, therefore, a less substantial benefit for octreotide as opposed to lanreotide [62]. However, the potential impact of this variability should be reconsidered given the results of a recent retrospective analysis of PRRT data. In this study, both SWOG and RECIST criteria provided comparable results and predicted PFS and overall survival in a similar way [63].

Finally, radiation exposure and the use of iodinated contrast media, unsuitable for subjects with renal function impairment or those at risk for allergic reactions, represent other disadvantages.

\section{Magnetic Resonance Imaging}

Morphologic MRI shares with CT the same limitations inherent in anatomic imaging for the assessment of response to treatment [34]. Moreover, the costs, the limited availability, the extensive patient cooperation required and the lower familiarity of the clinicians are also problematic. Additionally, MRI is unsuitable for the study of 
Table 3. Limitations of anatomic (a) and molecular imaging (b) techniques

a Anatomic imaging

\begin{tabular}{|c|c|c|c|}
\hline & MDCT & MRI & US techniques \\
\hline \multirow{3}{*}{$\begin{array}{l}\text { Technical } \\
\text { points }\end{array}$} & Radiation exposure & Cost & US techniques: operator dependency \\
\hline & $\begin{array}{l}\text { Use of iodinated contrast media may cause } \\
\text { renal impairment and other adverse effects }\end{array}$ & Lack of wide availability & $\begin{array}{l}\text { EUS: specialized expertise } \\
\text { required, lack of wide availability }\end{array}$ \\
\hline & $\begin{array}{l}\text { Strict dependency on the exact contrast } \\
\text { phase and dosage for comparability of } \\
\text { especially hypervascular lesions }\end{array}$ & Long examination procedure & IOUS: operator dependency \\
\hline \multirow[t]{6}{*}{$\begin{array}{l}\text { Clinical } \\
\text { points }\end{array}$} & $\begin{array}{l}\text { Difficult (re)assessment of small-volume } \\
\text { disease (e.g. small lymph nodes) }\end{array}$ & $\begin{array}{l}\text { Extensive patient cooperation } \\
\text { required }\end{array}$ & $\begin{array}{l}\text { Abdominal US and CEUS: low } \\
\text { sensitivity for GEP NETs, } \\
\text { suboptimal assessment of pancreas } \\
\text { and retroperitoneal lesions due to } \\
\text { overlying abdominal structures }\end{array}$ \\
\hline & $\begin{array}{l}\text { Difficult (re)assessment of large-volume } \\
\text { disease (coalescence) }\end{array}$ & $\begin{array}{l}\text { Difficult (re)assessment of } \\
\text { small-volume disease (e.g. small } \\
\text { lymph nodes) }\end{array}$ & $\begin{array}{l}\text { Difficult (re)assessment of } \\
\text { large-volume disease, especially in } \\
\text { the liver (poor demarcation, } \\
\text { coalescence) }\end{array}$ \\
\hline & & $\begin{array}{l}\text { Difficult assessment of small } \\
\text { thoracic lesions }\end{array}$ & Thorax cannot be examined \\
\hline & $\begin{array}{l}\text { Difficulty in capturing modifications in } \\
\text { slow-growing tumors }\end{array}$ & $\begin{array}{l}\text { Difficult (re)assessment of } \\
\text { large-volume disease (poor } \\
\text { demarcation, coalescence) }\end{array}$ & \\
\hline & $\begin{array}{l}\text { Difficulty in defining response (e.g. RECIST) } \\
\text { if necrosis/fibrosis/hemorrhage occurs } \\
\text { without a marked decrease in tumor size }\end{array}$ & $\begin{array}{l}\text { Difficulty in capturing } \\
\text { modifications in slow-growing } \\
\text { tumors }\end{array}$ & \\
\hline & & $\begin{array}{l}\text { Difficulty in defining response } \\
\text { (e.g. RECIST) if necrosis/ } \\
\text { fibrosis/hemorrhage occurs } \\
\text { without a marked decrease in } \\
\text { tumor size }\end{array}$ & \\
\hline
\end{tabular}

b Molecular imaging

\begin{tabular}{|c|c|c|c|c|c|}
\hline & ${ }^{111}$ In-pentetreotide & ${ }^{68} \mathrm{Ga}-\mathrm{PET}$ & ${ }^{18} \mathrm{~F}-\mathrm{DOPA}$ & ${ }^{11} \mathrm{C}-5-\mathrm{HTP}$ & ${ }^{18} \mathrm{FDG}$ \\
\hline \multirow{3}{*}{$\begin{array}{l}\text { Technical } \\
\text { points }\end{array}$} & Radiation exposure & Radiation exposure & Radiation exposure & Radiation exposure & Radiation exposure \\
\hline & Low spatial resolution & Lack of full validation & Lack of full validation & Lack of full validation & \\
\hline & $\begin{array}{l}\text { Long procedure } \\
\text { (2-4 days) }\end{array}$ & Lack of registration & & Lack of registration & \\
\hline \multirow[t]{2}{*}{$\begin{array}{l}\text { Clinical } \\
\text { points }\end{array}$} & $\begin{array}{l}\text { Low sensitivity for } \\
\text { insulinomas }\end{array}$ & $\begin{array}{l}\text { Possible interference } \\
\text { from cold analogues }\end{array}$ & $\begin{array}{l}\text { Lack of therapeutic } \\
\text { indications }\end{array}$ & $\begin{array}{l}\text { Available only in } \\
\text { specialized centers }\end{array}$ & $\begin{array}{l}\text { Not validated for } \\
\text { prognostication on } \\
\text { large series }\end{array}$ \\
\hline & $\begin{array}{l}\text { Possible interference } \\
\text { from cold analogues }\end{array}$ & & $\begin{array}{l}\text { Sensitivity seems } \\
\text { inferior to receptor } \\
\text { PET }\end{array}$ & $\begin{array}{l}\text { Lack of therapeutic } \\
\text { indications }\end{array}$ & \\
\hline
\end{tabular}

$\mathrm{GEP}=$ Gastroenteropancreatic 
small thoracic lesions because of the low signal-to-noise ratio in the lung, motion artifacts due to cardiac and respiratory activity and the lower spatial resolution as compared to CT [64].

\section{US Techniques}

The low sensitivity, the lack of reproducibility and operator dependency make abdominal US an inadequate tool for diagnosis and monitoring of therapy. For detection and characterization of liver lesions, CEUS is an excellent tool, but evaluation of the pancreas is restricted due to the presence of overlying bowel gas and other structures that impede optimal evaluation [65]. EUS and IOUS are similarly operator-dependent and require specialized expertise.

\section{Molecular Imaging (table 3b)}

SSR Imaging

The major limitation of conventional SRS with ${ }^{111}$ Inpentetreotide is the low spatial resolution (approximately $1.5 \mathrm{~cm}$ ) and, therefore, lower sensitivity compared to MRI and CT [37]. On a nonhybrid camera, lacking CT fusion, the procedure requires 2 and occasionally 3 days and, like any nuclear medicine procedure, has radiation exposure. The possibility of interference in the uptake by cold analogues and the low sensitivity for insulinomas due to their low SSR density, especially true for benign insulinomas, hamper SRS $[66,67]$.

Despite the orphan drug status of ${ }^{68} \mathrm{Ga}$-DOTATOC, ${ }^{68} \mathrm{Ga}$-DOTATATE and ${ }^{68} \mathrm{Ga}$-DOTANOC, neither of the ${ }^{68} \mathrm{Ga}$-DOTA-SSA are registered, which poses logistic difficulties. An additional major limitation of ${ }^{68} \mathrm{Ga}-\mathrm{SSA}$ $\mathrm{PET} / \mathrm{CT}$ is the lack of reproducibility due to the lack of standardization as regards the preparation, the production procedure and examination protocols. Because of this variability and since tissue distribution of ${ }^{68} \mathrm{Ga}$ DOTA-SSA is influenced by several other factors, PET measurements of SUV in tumor and normal tissues are not entirely reliable, although it has been demonstrated that $\mathrm{SUV}_{\max }$ at preoperative ${ }^{68} \mathrm{Ga}$-DOTANOC significantly correlated with the quantitative assessment of receptor density at immunohistochemistry for SSR2 and 5 in the surgical specimens [68].

\section{PET/CT with ${ }^{18} \mathrm{~F}$-DOPA}

Two limited-size studies report an inferior sensitivity of ${ }^{18} \mathrm{~F}$-DOPA compared to receptor PET $[54,55]$. This technique thus requires validation in robust series [69]. Another limitation is the lack of a therapeutic counterpart.

\section{PET/CT with ${ }^{11} \mathrm{C}-5$-HTP}

This modality requires an on-site cyclotron and is available only in a few specialized centers. The lack of full validation is a major limitation. In addition, there is no therapeutic application.

\section{PET/CT with ${ }^{18}$ FDG}

Despite some encouraging publications, the prognostic value in NETs has not been validated either in a large series or as a response to the available therapies [60].

\section{The Future}

Strategies to Advance Current Techniques (table 4) Morphologic Imaging

Currently, lesion volume comparisons are based purely on monodimensional (RECIST) or rarely bidimensional (SWOG/WHO) assessments. Neither technique adequately delineates the actual course of the disease, given the modest volumetric changes in NETs and/ or the possible simultaneous tissue modifications due to hemorrhage, fibrosis or tumor liquefaction. In this respect, attenuation measurement on $\mathrm{CT}$, to assess the changes of Hounsfield units, may better define the posttherapeutic tissue variations. The Choi criteria incorporate attenuation measurements on $\mathrm{CT}$ and add a $\geq 15 \%$ decrease of Hounsfield units to the $10 \%$ decrease in the longest lesion diameter as a parameter to indicate response [70]. These criteria, which were initially proposed for gastrointestinal stromal tumors, have also been tested for NETs [34] but require further validation.

A similar problem relates to the validation of examination protocols for comparing multiphasic imaging (CT and MRI) in order to ensure staging procedures are robust and reproducible. This is especially necessary for studies performed in different institutions which involve timing and duration of acquisition in relation to contrast medium injection, precise contrast medium dosage and contrast enhancement phase [71], and appearance of hypovascularization [72]. In order to obviate the integral problems inherent in a purely anatomical response evaluation, e.g. the variation in diameter, the integration of RECIST criteria with functional MRI parameters, such as arterial enhancement and necrosis, has been proposed. Following embolization of liver metastases, changes in each of these parameters have independently been associated with PFS [73].

SSR imaging has been demonstrated to timely predict the response to therapies such as SSA and PRRT [56, 
Table 4. Opportunities for anatomic and molecular imaging techniques

\begin{tabular}{|c|c|c|}
\hline & Advance in current techniques & Novel techniques and strategies \\
\hline \multirow[t]{4}{*}{ Anatomic imaging } & $\begin{array}{l}\text { Validation of Choi criteria for CT-based } \\
\text { therapy monitoring }\end{array}$ & $\begin{array}{l}\text { DWI techniques (ADC maps, pure diffusion } \\
\text { parameters) }\end{array}$ \\
\hline & $\begin{array}{l}\text { Integration of molecular imaging in RECIST } \\
\text { criteria (e.g. PERCIST) for therapy monitoring }\end{array}$ & DCE protocols for MRI, CT and US \\
\hline & $\begin{array}{l}\text { Integration of functional MRI parameters in } \\
\text { RECIST criteria (e.g. vascularization, necrosis) }\end{array}$ & Validation of high-power magnetic fields $(\geq 3 \mathrm{~T})$ \\
\hline & $\begin{array}{l}\text { Validation of scanning protocols for multphasic } \\
\text { imaging (CT and MRI) }\end{array}$ & \\
\hline \multirow[t]{8}{*}{ Molecular imaging } & $\begin{array}{l}{ }^{68} \mathrm{Ga}-\mathrm{SSA}-\mathrm{PET} \text { validation (preferred peptide, } \\
\text { peptide dose, preparation, quantification) }\end{array}$ & ${ }^{64} \mathrm{Cu}$-DOTA peptides \\
\hline & ${ }^{18} \mathrm{FDG}$ validation & ${ }^{68} \mathrm{Ga}-\mathrm{SSA}-\mathrm{PET} / \mathrm{MRI}$ \\
\hline & ${ }^{18} \mathrm{~F}-\mathrm{DOPA}$ validation for therapy monitoring & Impact of ${ }^{68} \mathrm{Ga}$-DOTA-SSA peptide mass \\
\hline & $\begin{array}{l}\text { Comparison of neuroendocrine metabolic and } \\
\text { receptor PET tracers in large series }\end{array}$ & SSR antagonists \\
\hline & & GLP-1 receptor peptides \\
\hline & & Gastrin peptides \\
\hline & & Bombesin peptides \\
\hline & & $\begin{array}{l}\text { Inhibitors of peripheral peptide degradations } \\
\text { (e.g. phosphoramidon) }\end{array}$ \\
\hline \multirow{3}{*}{$\begin{array}{l}\text { Merging biologic } \\
\text { information to } \\
\text { amplify accuracy }\end{array}$} & $\begin{array}{l}\text { Validation of criteria arbitrarily merging } \\
\text { biochemical, anatomic and molecular information }\end{array}$ & $\begin{array}{l}\text { Scores merging imaging information with liquid } \\
\text { biopsy (e.g. CTL, NET test) }\end{array}$ \\
\hline & & $\begin{array}{l}\text { Scores merging imaging information with } \\
\text { multianalyte assessment (NET test) }\end{array}$ \\
\hline & & Prognostic nomograms (CgA, MRI, CT, Ga-PET \\
\hline
\end{tabular}

74]. It has been proposed that a further measure that could increase the accuracy of therapy monitoring is the integration of ${ }^{68} \mathrm{Ga}$-SSA-PET/CT. This could be achieved in a similar way to the PERCIST criteria for FDG evaluation of responses to cancer therapy, where the SUV corrected for lean body mass, calculated in regions of interest of fixed diameter, is used to obtain a scale of response [75]. However, functional therapy monitoring with ${ }^{68} \mathrm{Ga}$-DOTATOC by using tumor SUV changes during PRRT, as compared to baseline, has not yet produced convincing results $[74,76]$. This could, at least partly, be related to differences in the administered amount of peptide between studies [77] and the fact that SUV does not seem to reflect SSR expression in tumors with a SUV $>20-25$ [78]. For therapy monitoring, diagnosis of progressive disease based on the appearance of new tumors could be more easily visualized with molecular imag- ing, particularly lesions that generally are difficult to diagnose by $\mathrm{CT}$, such as peritoneal lesions and bone metastases $[79,80]$.

\section{Functional Imaging}

In order to ensure acceptance by clinicians, ${ }^{68} \mathrm{Ga}$-SSA$\mathrm{PET} / \mathrm{CT}$ needs to be developed as an efficient and reproducible molecular imaging procedure. There are several requirements that include: the choice of peptide, type of radiopharmaceutical preparation procedure and examination protocol in order to ensure reproducibility of the technique.

None of the three peptides currently in use (-TOC, -TATE and -NOC) demonstrates a clear diagnostic superiority over the others $[81,82]$. Regarding preparation procedures, besides the European Pharmacopeia monograph on DOTATOC, the other ${ }^{68} \mathrm{Ga}$-SSA preparations are syn- 
thesized according to local, nonstandardized routines. As regards the reproducibility of the PET technique, despite some degree of uniformity offered by the EANM guidelines, current examination protocols vary in the acquisition time point in relation to tracer administration and in the amount of administered peptide. Also pertaining to this, there are large variations between centers on the view of the optimal preparation of the patients as regards the time interval between cold SSA injection and imaging. These factors, together with the inherent problems of PET measurements in tumors with high ${ }^{68} \mathrm{Ga}$-SSA-uptake, as discussed previously [78], make SUV, the semiquantitative parameter to express uptake, less reliable. Moreover, SUV is intrinsically variable and may fluctuate among individual PET scanners and between centers unless these are cross-calibrated. Thus, the reproducibility of ${ }^{68} \mathrm{Ga}-\mathrm{SSA}-\mathrm{PET} / \mathrm{CT}$ may vary with the type of preparation and its SSR subtype affinity profile, the examination time after tracer injection, scanning times (resulting in different phases of tumor uptake at the subsequent bed positions), the SSR saturation in tumors and nontumor tissues as a consequence of the injected amount of peptide and the relation to administration of cold SSA [83] and after splenectomy [84]. The use of tumor-to-normal-tissue ratios, such as tumor-to-liver and tumor-to-spleen, is a means to decrease the influence of these many factors that may reduce the accuracy of SUV measurements $[74,85]$. Delineation of the patient's total tumor load, usually assisted by semiautomated software, has also been tested to calculate the 'total somatostatin receptor tumor volume' [78] or molecular tumor volume [86]. Particularly in larger centers, treating patients with PRRT, the increasing use of ${ }^{68} \mathrm{Ga}-\mathrm{SSA}$-PET/CT has rendered SRS obsolete, and the only remaining indication for SRS is to assess the patient's eligibility for PRRT. Therefore, an objective adaptation of the so-called 'Rotterdam scale' or 'Krenning scale' to ${ }^{68} \mathrm{Ga}$-SSA-PET/CT needs to be developed to validate its predictive value.

Another important issue is a clinical validation of ${ }^{18} \mathrm{FDG}$ uptake as a prognostic marker for NET aggression and as a tracer to monitor NET therapy response [27, 28]. Moreover, ${ }^{18} \mathrm{~F}$-DOPA should be validated and compared to ${ }^{68} \mathrm{Ga}$-SSA-PET/CT in large series [31].

\section{Novel Techniques and Strategies}

\section{Morphological Imaging}

Diffusion-Weighted MRI

Diffusion-Weighted MRI (DWI) has been reported to be a sensitive modality to detect and characterize liver me- tastases from NETs, with $71 \%$ sensitivity and $85-100 \%$ specificity. This is higher than the commonly used T2 fast spin echo or dynamic gadolinium-enhanced MRI [87]. DWI, therefore, is currently the most promising technique for investigating NETs, usually in combination with ${ }^{68} \mathrm{Ga}$ SSA-PET/CT [88]. Interestingly, the newly introduced hybrid technique PET/MRI has not yet resulted in an increased sensitivity compared to the stand-alone techniques [89]. DWI for oncologic imaging is based on the restricted diffusion of water molecules in highly cellular tissue such as tumors and has shown potential for distinguishing exocrine and endocrine pancreatic tumors [90] and G1 from G2-G3 pancreatic neuroendocrine lesions by means of quantifying the tumor's apparent diffusion coefficient (ADC) in the images (ADC map) [91]. ADC has been shown to correlate with Ki67 [92]. To overcome the possible interference of tumor microcirculation in the measurements, an intravoxel incoherent motion model has been proposed to separate the true tissue diffusion; this results in a better characterization of pancreatic lesions [93]. Together with tumor size, the pure diffusion coefficient was able to differentiate G1 from G2 pancreatic NETs [94].

\section{Dynamic Contrast-Enhanced Imaging}

Dynamic contrast-enhanced (DCE) imaging is applied to MRI, CT and US $[31,34,95]$. In contrast to PET/CT, it is not a whole-body technique, and the examination generally needs to be focused to include a limited axial field of view. The technique requires substantial validation in consideration of the large intraindividual variability $(20 \%$ for DCE MRI) and the lack of linear correlation between gadolinium concentrations in the tissue and the resulting signal intensity $[31,96]$. It has been recently demonstrated that perfusion parameters at DCE MRI have a definite pattern in malignant liver metastases. The flow-related parameters, such as the arterial plasma flow and the arterial flow fraction, are both correlated with the mean SUV derived from ${ }^{68} \mathrm{Ga}$-DOTATATE-PET (negatively) and ${ }^{18}$ FDG-PET (positively). This suggests that functional and molecular techniques evaluate different aspects of liver function and may offer complementary information [97].

DCE MRI parameters have also been used to monitor the response to PRRT [98]. Specific parameters related to perfusion and tissue exchange were spatially correlated with the heterogeneous uptake of ${ }^{111}$ In-pentetreotide in a pancreatic NET model in rats [99]. Regions with high exchange-related parameters demonstrated high tracer uptake, and these parameters were better predictors of uptake as compared to parameters associated with the total 
amount of contrast. Clinical confirmation of these observations would have important therapeutic and prognostic implications [99].

\section{Functional Imaging}

${ }^{64} \mathrm{Cu}$ Labeling

SSA labeled with ${ }^{64} \mathrm{Cu}$ is of interest due to the excellent image quality compared to conventional scintigraphy and the possibility of imaging at a later time compared to ${ }^{68} \mathrm{Ga}-\mathrm{SSA}$, thus matching more closely the kinetics of receptor uptake, namely 3 and $24 \mathrm{~h}$ after injection, due to the 12.5-hour half-life. The latter allows for easy distribution to other diagnostic centers. Drawbacks are the need for a cyclotron for its production and a higher radiation dose to the patient as compared to ${ }^{68} \mathrm{Ga}$-SSA $\left({ }^{68} \mathrm{Gat}_{1 / 2} 68\right.$ min). Direct comparisons with ${ }^{68} \mathrm{Ga}-\mathrm{SSA}-\mathrm{PET} / \mathrm{CT}$ are warranted [24].

\section{Novel SSA Antagonists}

Besides radiolabeled SSA, the workhorse of nuclearmedicine NET imaging for 2 decades, alternative radiopharmaceuticals with an increased diagnostic accuracy [100] have been identified and developed. In this respect, the use of SSR antagonists represents a highly promising strategy [101]. The lack of internalization and the recognition of increased binding sites is an inversion of the current paradigm of agonist binding and is, therefore, of great interest to explore. Paradoxically, antagonists result in a higher and longer retention in tumors and better imaging results [102]. In vitro, the ${ }^{177} \mathrm{Lu}$-labeled compound DOTA-BASS binds to more receptor sites than the agonist DOTATATE, while, in vivo, the same peptide labeled with ${ }^{111}$ In demonstrated a higher tumor uptake than ${ }^{111}$ In-pentetreotide. This implies a higher sensitivity compared to conventional scintigraphy and may translate, using the therapeutic counterpart, into a greater treatment benefit $[102,103]$.

\section{GLP-1 Receptor Peptides}

The development of novel receptor peptides that can identify a particular tumor or one with a specific secretory product needs to be investigated. A number of peptides have been tested in preclinical and clinical trials. Among these, GLP-1 receptor peptides, like ${ }^{111}$ In-exendin-4 for the localization of occult insulinomas, are the most advanced for clinical application [104]. ${ }^{111}$ In-exendin- 4 addresses the general paucity of SSRs in insulinoma. GLP-R and SSR imaging, therefore, demonstrate the biologically mutable aspect of insulinomas, which may be GLP-R positive and SSR negative or vice versa, a reflec- tion of their malignant phenotype [105]. In this respect, ${ }^{68} \mathrm{Ga}$-exendin- 4 has been recently tested for PET/CT imaging in clinical practice $[106,107]$.

Others

Other receptor peptides potentially of use in NET imaging include GRP receptor ligands, such as bombesin agonists and antagonists labeled with ${ }^{99 \mathrm{~m}} \mathrm{Tc}$ or with ${ }^{68} \mathrm{Ga}$, and gastrin/cholecystokinin analogs, such as ${ }^{111}$ In-labeled minigastrin. The low plasma stability and high kidney retention, however, classically limited the diffusion of these peptides [100]. Nevertheless, newer, more stable molecules and the coadministration of specific enzyme inhibitors, such as the neutral endopeptidase inhibitor phosphoramidon, can be utilized to increase the bioavailability of these compounds [108]. Alternative strategies include the use of ${ }^{89} \mathrm{Zr}$-labeled bevacizumab to evaluate NETs of different origins treated with everolimus. A decrease in the SUV during treatment suggested that this technique could be an early predictor of the efficacy of antiangiogenesis treatments [109].

\section{Integration of Biological Information to Amplify Accuracy}

\section{Biological Indices}

In order to advance NET diagnosis and better predict prognosis and optimize therapies, there is a need to integrate the biological information of tumor pathophysiology with anatomic and molecular diagnostic strategies. Thus, the relationship between the intrinsic variability of individual NET cells (EC, $\beta, E C L, D$, Clara, etc.) that comprise the different tumor types and imaging strategies requires investigation. This should include a delineation of histopathological indices, high-throughput molecular analyses, receptor subtyping and characterization as well as the determination of metabolic parameters that define function and proliferation.

\section{Nomograms}

It is clear that monoanalyte-derived information can never be as effective as the product of multianalyte parameters. Thus, an image alone is, by definition, limited by the lack of additional, relevant parameters that can be integrated into an amplifiable diagnostic quotient. Inclusion of such additional material, in a mathematical probability index, or in a matrix or via a nomogram, has proved of considerable added value in other disciplines [110].
Bodei/Sundin/Kidd/Prasad/Modlin 
Fig. 3. Time line of imaging development in NETs. ${ }^{131}$ I-MIBG $={ }^{131}$ I-metaiodobenzylguanidine; ${ }^{11} \mathrm{C}-\mathrm{HTP}={ }^{11} \mathrm{C}$-hydroxytryptophan.

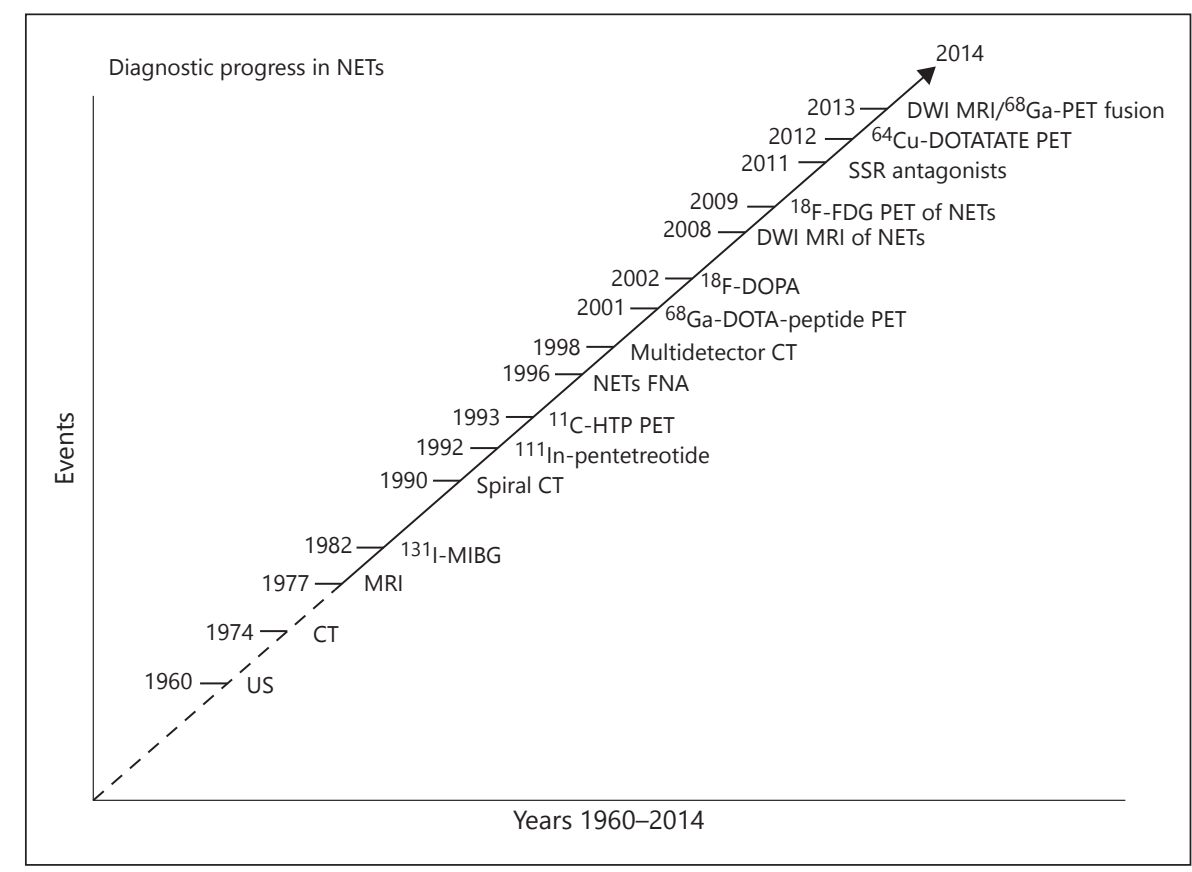

Recently, various studies have explored the combination of the information deriving from imaging with clinical and biologic data, in order to obtain predictive algorithms that are able to confer a higher accuracy to diagnostic techniques. As an example, a combination of morphologic information, such as tumor size $>4 \mathrm{~cm}$ and presence of lymph nodes when combined with biological information, such as the tumor grade, has been utilized in a model, deriving from the multiple logistic regression of a retrospective series, that is able to predict the preoperative risk of lymph node metastasis in nonfunctioning pancreatic NETs [111].

A more detailed nomogram was constructed to determine prognosis of small intestine NETs. This utilized 15 clinical and biological variables, such as age, symptoms, 5-HIAA, CgA, tumor size, invasion, metastasis, histology, Ki67 index and adopted therapy. The resulting score was able to identify significant differences in survival, thus demonstrating that a multilevel parallel assessment of different forms of tumor-/patient-relevant information may be an appropriate tool that can strengthen both diagnostic and prognostic accuracy [110].

Recently, a mathematical model incorporating proliferation, infiltration, metabolism and mass effect has been proposed to estimate the tumor growth in pancreatic NETs. This includes integration of the theoretical equations with the observations derived from dual-phase con- trast-enhanced CT and FDG-PET. However, in the absence of tumors' inherent biological parameters, the model only reflected a current situation and could not predict future progression [112].

To amplify information provided by NET imaging techniques, the integration of tumor features and bloodbased biomarkers into prognostic nomograms may be useful. An informative source of information would be the integration of tumor data, such as circulating tumor cells and relevant genes, detected through mRNA measurement or circulating autoantibodies, with imaging [113]. In particular, circulating genomic data obtained from blood (tumor transcript profile or signature) at the time of imaging could be combined with morphologic or functional tumor characteristics and, thus, allow for the development of a personalized predictive assessment of tumor status before, during and after treatment [3].

\section{Coda}

Diagnostic imaging has substantially advanced in the past 40 years (fig. 3 ). This development has been facilitated by the collaboration between medicine professionals and industrial partners. It is evident that progress occurs through team-based science, and future multidisciplinary teams in our hospitals need not only include 
medicine professionals but also experts on genomics, laboratory medicine and epidemiology. Given the complexity of the carcinogenic process, the intrinsic heterogeneity of cancer and tumor microenvironment, it is unlikely that any single diagnostic test will be effective. Rather, NET diagnosis will be a process utilizing a variety of methods including genomics-epigenomics-proteomics on biosamples such as blood, urine and tumor tissue in combination with anatomical and molecular imaging (hybrid imaging) for localization, delineation and staging of the disease, as the basis for optimal selection of therapy.
Future advances in NET diagnosis need to consider two realities. Firstly, a short-term accelerated strategy to focus upon validation of the present techniques or sequences of techniques. The second is a long-term strategy, to develop a more comprehensive multilevel integration of biologic and genomic information to provide added value to the imaging techniques. This will aim at facilitating recognition of the complete status of an individual tumor. Thus, a fusion product of molecular and genomic information with tumor imaging is likely to be the quintessence of future NET diagnosis and define the progress from darkness to light.

\section{References}

1 Modlin IM, Oberg K, Chung DC, et al: Gastroenteropancreatic neuroendocrine tumours. Lancet Oncol 2008;9:61-72.

2 Duque M, Modlin IM, Gupta A, et al: Biomarkers in neuroendocrine tumors. JOP 2013;14:372-376

3 Modlin I, Drozdov I, Kidd M: The Identification of gut neuroendocrine tumor disease by multiple synchronous transcript analysis in blood. PLoS One 2013; 63364.

4 Modlin IM, Latich I, Zikusoka M, et al: Gastrointestinal carcinoids: the evolution of diagnostic strategies. J Clin Gastroenterol 2006; 40:572-582.

5 Gotthardt M, Dirkmorfeld LM, Wied MU, et al: Influence of somatostatin receptor scintigraphy and CT/MRI on the clinical management of patients with gastrointestinal neuroendocrine tumors: an analysis in 188 patients. Digestion 2003;68:80-85.

6 Oberg K: Diagnostic work-up of gastroenteropancreatic neuroendocrine tumors. Clinics (Sao Paulo) 2012;67:109-112.

7 Sundin A: Radiological and nuclear medicine imaging of gastroenteropancreatic neuroendocrine tumours. Best Pract Res Clin Gastroenterol 2012;26:803-818.

$\checkmark 8$ Sundin A, Vullierme MP, Kaltsas G, et al: ENETS consensus guidelines for the standards of care in neuroendocrine tumors: radiological examinations. Neuroendocrinology 2009;90:167-183.

-9 Ichikawa T, Peterson MS, Federle MP, et al: Islet cell tumor of the pancreas: biphasic CT versus $\mathrm{MR}$ imaging in tumor detection. Radiology 2000;216:163-171.

10 Rappeport ED, Hansen CP, Kjaer A, et al: Multidetector computed tomography and neuroendocrine pancreaticoduodenal tumors. Acta Radiol 2006;47:248-256.

-11 Sahani DV, Bonaffini PA, Fernandez-Del Castillo C, et al: Gastroenteropancreatic neuroendocrine tumors: role of imaging in diagnosis and management. Radiology 2013;266: $38-61$.
12 Khashab MA, Yong E, Lennon AM, et al: EUS is still superior to multidetector computerized tomography for detection of pancreatic neuroendocrine tumors. Gastrointest Endosc 2011;73:691-696.

13 Johanssen S, Boivin M, Lochs $\mathrm{H}$, et al: The yield of wireless capsule endoscopy in the detection of neuroendocrine tumors in comparison with CT enteroclysis. Gastrointest En dosc 2006;63:660-665.

14 Kamaoui I, De-Luca V, Ficarelli S, et al: Value of CT enteroclysis in suspected small-bowel carcinoid tumors. AJR Am J Roentgenol 2010; 194:629-633.

15 Van Weyenberg SJ, Meijerink MR, Jacobs MA, et al: MR enteroclysis in the diagnosis of small-bowel neoplasms. Radiology 2010;254: 765-773.

16 Masselli G, Polettini E, Casciani E, et al: Small-bowel neoplasms: prospective evaluation of MR enteroclysis. Radiology 2009;251: 743-750.

$>17$ Krausz Y, Keidar Z, Kogan I, et al: SPECT/CT hybrid imaging with ${ }^{111} \mathrm{In}$-pentetreotide in assessment of neuroendocrine tumours. Clin Endocrinol (Oxf) 2003;59:565-573.

18 Teunissen JJ, Kwekkeboom DJ, Valkema R, et al: Nuclear medicine techniques for the imaging and treatment of neuroendocrine tumours. Endocr Relat Cancer 2011;18:S27S51.

19 Hofmann M, Maecke H, Borner R, et al: Biokinetics and imaging with the somatostatin receptor PET radioligand ${ }^{68} \mathrm{Ga}$-DOTATOC: preliminary data. Eur J Nucl Med 2001;28: 1751-1757.

20 Al-Nahhas A, Fanti S: Radiolabelled peptides in diagnosis and therapy: an introduction. Eur J Nucl Med Mol Imaging 2012;39(suppl 1):S1-S3

21 Gabriel M, Decristoforo C, Kendler D, et al: ${ }^{68} \mathrm{Ga}$-DOTA-Tyr3-octreotide PET in neuroendocrine tumors: comparison with somatostatin receptor scintigraphy and CT. J Nucl Med 2007;48:508-518.
22 Ambrosini V, Campana D, Tomassetti P, Fanti S: ${ }^{68} \mathrm{Ga}$-labelled peptides for diagnosis of gastroenteropancreatic NET. Eur J Nucl Med Mol Imaging 2012;39(suppl 1):S52-S60.

23 Srirajaskanthan R, Kayani I, Quigley AM, et al: The role of ${ }^{68} \mathrm{Ga}$-DOTATATE PET in patients with neuroendocrine tumors and negative or equivocal findings on ${ }^{111}$ In-DTPA-octreotide scintigraphy. J Nucl Med 2010;51:875-882.

24 Pfeifer A, Knigge U, Mortensen J, et al: Clinical PET of neuroendocrine tumors using ${ }^{64} \mathrm{Cu}$-DOTATATE: first-in-humans study. J Nucl Med 2012;53:1207-1215.

25 Jager PL, Chirakal R, Marriott CJ, et al: 6-L- ${ }^{18} \mathrm{~F}$-fluorodihydroxyphenylalanine PET in neuroendocrine tumors: basic aspects and emerging clinical applications. J Nucl Med 2008;49:573-586.

26 Orlefors H, Sundin A, Garske U, et al: Wholebody ${ }^{11} \mathrm{C}$-5-hydroxytryptophan positron emission tomography as a universal imaging technique for neuroendocrine tumors: comparison with somatostatin receptor scintigraphy and computed tomography. J Clin Endocrinol Metab 2005;90:3392-3400.

27 Binderup T, Knigge U, Loft A, et al: Functional imaging of neuroendocrine tumors: a headto-head comparison of somatostatin receptor scintigraphy, ${ }^{123} \mathrm{I}-\mathrm{MIBG}$ scintigraphy, and ${ }^{18}$ F-FDG PET. J Nucl Med 2010;51:704-712.

$\checkmark 28$ Severi S, Nanni O, Bodei L, et al: Role of ${ }^{18} \mathrm{FDG}$ PET/CT in patients treated with ${ }^{177} \mathrm{Lu}-$ DOTATATE for advanced differentiated neuroendocrine tumours. Eur J Nucl Med Mol Imaging 2013;40:881-888.

$>29$ Binderup T, Knigge U, Loft A, et al: ${ }^{18}$ F-fluorodeoxyglucose positron emission tomography predicts survival of patients with neuroendocrine tumors. Clin Cancer Res 2010;16: 978-985.

30 Ezziddin S, Adler L, Sabet A, et al: Prognostic stratification of metastatic gastroenteropancreatic neuroendocrine neoplasms by ${ }^{18} \mathrm{~F}$ FDG PET: feasibility of a metabolic grading system. J Nucl Med 2014;55:1260-1266. 
31 Sundin A, Rockall A: Therapeutic monitoring of gastroenteropancreatic neuroendocrine tumors: the challenges ahead. Neuroendocrinology 2012;96:261-271.

- 32 Ganeshan D, Bhosale P, Yang T, et al: Imaging features of carcinoid tumors of the gastrointestinal tract. AJR Am J Roentgenol 2013;201: 773-786.

-33 Arigoni S, Ignjatovic S, Sager P, et al: Diagnosis and prediction of neuroendocrine liver metastases: a protocol of six systematic reviews. JMIR Res Protoc 2013;2:e60.

- 34 de Mestier L, Dromain C, d'Assignies G, et al: Evaluating digestive neuroendocrine tumor progression and therapeutic responses in the era of targeted therapies: state of the art. Endocr Relat Cancer 2014;21:R105-R120.

- 35 Kim KW, Krajewski KM, Nishino M, et al: Update on the management of gastroenteropancreatic neuroendocrine tumors with emphasis on the role of imaging. AJR Am J Roentgenol 2013;201:811-824.

36 Hwang J, Kim YK, Park MJ, et al: Liver MRI at 3.0 tesla: comparison of image quality and lesion detectability between single-source conventional and dual-source parallel radiofrequency transmissions. J Comput Assist Tomogr 2012;36:546-553.

-37 Dromain C, de Baere T, Lumbroso J, et al: Detection of liver metastases from endocrine tumors: a prospective comparison of somatostatin receptor scintigraphy, computed tomography, and magnetic resonance imaging. J Clin Oncol 2005;23:70-78.

- 38 Schraml C, Schwenzer NF, Sperling O, et al: Staging of neuroendocrine tumours: comparison of $\left[{ }^{68} \mathrm{Ga}\right]$ DOTATOC multiphase PET/ $\mathrm{CT}$ and whole-body MRI. Cancer Imaging 2013;13:63-72.

-39 Morana G, Salviato E, Guarise A: Contrast agents for hepatic MRI. Cancer Imaging 2007; 7:S24-S27.

40 Dromain C, de Baere T, Baudin E, et al: MR im aging of hepatic metastases caused by neuroendocrine tumors: comparing four techniques. AJR Am J Roentgenol 2003;180:121-128.

41 Schima W: MRI of the pancreas: tumours and tumour-simulating processes. Cancer Imaging 2006;6:199-203.

42 Heller MT, Shah AB: Imaging of neuroendocrine tumors. Radiol Clin North Am 2011;49: 529-548.

43 Modlin I, Gustafsson B, Kidd M: Gastrointestinal carcinoid tumors; in Howden C (ed): Advances in Digestive Disease. Bethesda, AGA Institute Press, 2007, pp 203-218.

-44 Puli SR, Kalva N, Bechtold ML, et al: Diagnostic accuracy of endoscopic ultrasound in pancreatic neuroendocrine tumors: a systematic review and meta-analysis. World J Gastroenterol 2013;19:3678-3684.

45 Gupta RK, Naran S, Lallu S, et al: Fine needle aspiration diagnosis of neuroendocrine tumors in the liver. Pathology 2000;32:16-20.

-46 Pepe G, Chiti A: Reply to comment on Pepe et al: Somatostatin receptor SPECT. Eur J Nucl Med Mol Imaging 2013;40:302.
47 Lebtahi R, Cadiot G, Sarda L, et al: Clinical impact of somatostatin receptor scintigraphy in the management of patients with neuroendocrine gastroenteropancreatic tumors. J Nucl Med 1997;38:853-858.

48 Kwekkeboom DJ, Kam BL, van Essen M, et al: Somatostatin-receptor-based imaging and therapy of gastroenteropancreatic neuroendocrine tumors. Endocr Relat Cancer 2010; 17:R53-R73.

49 Termanini B, Gibril F, Reynolds JC, et al: Value of somatostatin receptor scintigraphy: a prospective study in gastrinoma of its effect on clinical management. Gastroenterology 1997;112:335-347.

50 Cadiot G, Bonnaud G, Lebtahi R, et al: Usefulness of somatostatin receptor scintigraphy in the management of patients with ZollingerEllison syndrome. Groupe de Recherche et d'Etude du Syndrome de Zollinger-Ellison (GRESZE). Gut 1997;41:107-114.

51 Ambrosini V, Fanti S: ${ }^{68}$ Ga-DOTA-peptides in the diagnosis of NET. PET Clinics 2014;9: $37-42$.

52 Laurent V, Olivier P: Imaging and PET/CT evaluation of GI tract cancers (in French). J Radiol 2008;89:413-435; quiz 436-437.

53 Decristoforo C, Pickett RD, Verbruggen A: Feasibility and availability of ${ }^{68} \mathrm{Ga}$-labelled peptides. Eur J Nucl Med Mol Imaging 2012; 39:S31-S40

54 Ambrosini V, Tomassetti P, Castellucci P, et al: Comparison between ${ }^{68} \mathrm{Ga}$-DOTA-NOC and ${ }^{18} \mathrm{~F}$-DOPA PET for the detection of gastro-entero-pancreatic and lung neuro-endocrine tumours. Eur J Nucl Med Mol Imaging 2008;35:1431-1438.

55 Haug A, Auernhammer CJ, Wangler B, et al: Intraindividual comparison of ${ }^{68} \mathrm{Ga}$-DOTATATE and ${ }^{18} \mathrm{~F}$-DOPA PET in patients with well-differentiated metastatic neuroendocrine tumours. Eur J Nucl Med Mol Imaging 2009;36:765-770.

56 Campana D, Ambrosini V, Pezzilli R, et al: Standardized uptake values of ${ }^{68} \mathrm{Ga}$ DOTANOC PET: a promising prognostic tool in neuroendocrine tumors. J Nucl Med 2010;51:353-359.

57 Ambrosini V, Campana D, Bodei L, et al: ${ }^{68} \mathrm{Ga}$-DOTANOC PET/CT clinical impact in patients with neuroendocrine tumors. J Nucl Med 2010;51:669-673.

58 Koopmans KP, Neels OC, Kema IP, et al: Improved staging of patients with carcinoid and islet cell tumors with ${ }^{18} \mathrm{~F}$-dihydroxy-phenylalanine and ${ }^{11} \mathrm{C}$-5-hydroxy-tryptophan positron emission tomography. J Clin Oncol 2008;26:1489-1495.

59 Imperiale A, Rust E, Gabriel S, et al: ${ }^{18} \mathrm{~F}$-fluorodihydroxyphenylalanine PET/CT in patients with neuroendocrine tumors of unknown origin: relation to tumor origin and differentiation. J Nucl Med 2014;55:367372.

60 Toumpanakis C, Kim MK, Rinke A, et al: Combination of cross-sectional and molecular imaging studies in the localization of gas- troenteropancreatic neuroendocrine tumors. Neuroendocrinology 2014;21:21.

61 Castano JP, Sundin A, Maecke HR, et al: Gastrointestinal neuroendocrine tumors (NETs): new diagnostic and therapeutic challenges. Cancer Metastasis Rev 2014;5:5.

62 Caplin ME, Pavel M, Cwikla JB, et al: Lanreotide in metastatic enteropancreatic neuroendocrine tumors. N Engl J Med 2014;371:224233.

63 van Vliet EI, Krenning EP, Teunissen JJ, et al: Comparison of response evaluation in patients with gastroenteropancreatic and thoracic neuroendocrine tumors after treatment with $\left[{ }^{177} \mathrm{Lu}\right.$-DOTA0, Tyr3] octreotate. J Nucl Med 2013;54:1689-1696.

64 Kurihara Y, Matsuoka S, Yamashiro T, et al: MRI of pulmonary nodules. AJR Am J Roentgenol 2014;202:W210-W216.

65 Tan EH, Tan CH: Imaging of gastroenteropancreatic neuroendocrine tumors. World J Clin Oncol 2011;2:28-43.

-66 Bombardieri E, Ambrosini V, Aktolun C, et al: ${ }^{111}$ In-pentetreotide scintigraphy: procedure guidelines for tumour imaging. Eur J Nucl Med Mol Imaging 2010;37:14411448.

67 Virgolini I, Ambrosini V, Bomanji JB, et al: Procedure guidelines for PET/CT tumour imaging with ${ }^{68} \mathrm{Ga}$-DOTA-conjugated peptides: ${ }^{68} \mathrm{Ga}$-DOTA-TOC, ${ }^{68} \mathrm{Ga}$-DOTA-NOC, ${ }^{68} \mathrm{Ga}$ DOTA-TATE. Eur J Nucl Med Mol Imaging 2010;37:2004-2010.

68 Kaemmerer D, Peter L, Lupp A, et al: Molecular imaging with ${ }^{68} \mathrm{Ga}$-SSTR PET/CT and correlation to immunohistochemistry of somatostatin receptors in neuroendocrine tumours. Eur J Nucl Med Mol Imaging 2011;38: 1659-1668

69 Schillaci O: ${ }^{18} \mathrm{~F}-\mathrm{DOPA}$ and other radiopharmaceuticals for imaging unknown primary neuroendocrine tumors. J Nucl Med 2014;55: 357-359.

70 Choi H, Charnsangavej C, Faria SC, et al: Correlation of computed tomography and positron emission tomography in patients with metastatic gastrointestinal stromal tumor treated at a single institution with imatinib mesylate: proposal of new computed tomography response criteria. J Clin Oncol 2007;25: 1753-1759.

71 Ng CS, Hobbs BP, Chandler AG, et al: Metastases to the liver from neuroendocrine tumors: effect of duration of scan acquisition on CT perfusion values. Radiology 2013;269: 758-767.

72 Denecke T, Baur AD, Ihm C, et al: Evaluation of radiological prognostic factors of hepatic metastases in patients with non-functional pancreatic neuroendocrine tumors. Eur J Radiol 2013;82:e550-e555.

73 Ceelen F, Theisen D, de Albeniz XG, et al: Towards new response criteria in neuroendocrine tumors: which changes in MRI parameters are associated with longer progression-free survival after radioembolization of liver metastases? J Magn Reson Imaging 2014;21:24569. 
74 Haug AR, Auernhammer CJ, Wangler B, et al: ${ }^{68} \mathrm{Ga}$-DOTATATE PET/CT for the early prediction of response to somatostatin receptormediated radionuclide therapy in patients with well-differentiated neuroendocrine tumors. J Nucl Med 2010;51:1349-1356.

75 Wahl RL, Jacene H, Kasamon Y, et al: From RECIST to PERCIST: evolving considerations for PET response criteria in solid tumors. J Nucl Med 2009;50:122S-150S.

76 Gabriel M, Oberauer A, Dobrozemsky G, et al: ${ }^{68} \mathrm{Ga}$-DOTA-Tyr3-octreotide PET for assessing response to somatostatin-receptormediated radionuclide therapy. J Nucl Med 2009;50:1427-1434.

-77 Velikyan I, Sundin A, Eriksson B, et al: In vivo binding of $\left[{ }^{68} \mathrm{Ga}\right]$-DOTATOC to somatostatin receptors in neuroendocrine tumours impact of peptide mass. Nucl Med Biol 2010 37:265-275.

78 Velikyan I, Sundin A, Sorensen J, et al: Quantitative and qualitative intrapatient comparison of ${ }^{68} \mathrm{Ga}$-DOTATOC and ${ }^{68} \mathrm{Ga}$ DOTATATE: net uptake rate for accurate quantification. J Nucl Med 2014;55:204-210.

-79 Putzer D, Gabriel M, Henninger B, et al: Bone metastases in patients with neuroendocrine tumor: ${ }^{68} \mathrm{Ga}$-DOTA-Tyr3-octreotide PET in comparison to CT and bone scintigraphy. J Nucl Med 2009;50:1214-1221.

80 Carreras C, Kulkarni HR, Baum RP: Rare metastases detected by ${ }^{68} \mathrm{Ga}$-somatostatin receptor $\mathrm{PET} / \mathrm{CT}$ in patients with neuroendocrine tumors. Recent Results Cancer Res 2013;194: 379-384.

81 Poeppel TD, Binse I, Petersenn S, et al: ${ }^{68} \mathrm{Ga}$ DOTATOC versus ${ }^{68} \mathrm{Ga}$-DOTATATE PET/ $\mathrm{CT}$ in functional imaging of neuroendocrine tumors. J Nucl Med 2011;52:1864-1870.

82 Kabasakal L, Demirci E, Ocak M, et al: Comparison of ${ }^{68} \mathrm{Ga}$-DOTATATE and ${ }^{68} \mathrm{Ga}$ DOTANOC PET/CT imaging in the same patient group with neuroendocrine tumours. Eur J Nucl Med Mol Imaging 2012;39:12711277.

83 Sabet A, Nagarajah J, Dogan AS, et al: Does PRRT with standard activities of ${ }^{177} \mathrm{Lu}-\mathrm{oc}$ treotate really achieve relevant somatostatin receptor saturation in target tumor lesions? insights from intra-therapeutic receptor imaging in patients with metastatic gastroenteropancreatic neuroendocrine tumors. EJNMMI Res 2013;3:82.

84 Kratochwil C, Mavriopoulou E, Rath D, et al: Comparison of ${ }^{68} \mathrm{Ga}$-DOTATOC biodistribution in patients with and without splenectomy. Q J Nucl Med Mol Imaging 2014;2:2.

85 Garin E, Le Jeune F, Devillers A, et al: Predictive value of ${ }^{18} \mathrm{~F}$-FDG PET and somatostatin receptor scintigraphy in patients with metastatic endocrine tumors. J Nucl Med 2009;50: 858-864.

86 Baum RP, Kulkarni HR: THERANOSTICS: 98 from molecular imaging using Ga-68 labeled tracers and PET/CT to personalized radionuclide therapy - the Bad Berka experience. Theranostics 2012;2:437-447.
87 d'Assignies G, Fina P, Bruno O, et al: High sensitivity of diffusion-weighted MR imaging for the detection of liver metastases from neuroendocrine tumors: comparison with $\mathrm{T} 2$ weighted and dynamic gadolinium-enhanced MR imaging. Radiology 2013;26:26.

88 Wulfert S, Kratochwil C, Choyke PL, et al: Multimodal imaging for early functional response assessment of Y-/Lu-DOTATOC peptide receptor targeted radiotherapy with DWMRI and Ga-DOTATOC-PET/CT. Mol Imaging Biol 2014;14:14.

89 Mayerhoefer ME, Ba-Ssalamah A, Weber M, et al: Gadoxetate-enhanced versus diffusionweighted MRI for fused Ga-68-DOTANOC PET/MRI in patients with neuroendocrine tumours of the upper abdomen. Eur Radiol 2013;23:1978-1985.

90 Concia M, Sprinkart AM, Penner AH, et al: Diffusion-weighted magnetic resonance imaging of the pancreas: diagnostic benefit from an intravoxel incoherent motion model-based 3 b-value analysis. Invest Radiol 2014;49:93-100.

91 Jang KM, Kim SH, Lee SJ, et al: The value of gadoxetic acid-enhanced and diffusionweighted MRI for prediction of grading of pancreatic neuroendocrine tumors. Acta Radiol 2014;55:140-148.

92 Wang Y, Chen ZE, Yaghmai V, et al: Diffusion-weighted MR imaging in pancreatic endocrine tumors correlated with histopathologic characteristics. J Magn Reson Imaging 2011;33:1071-1079.

-93 Kang KM, Lee JM, Yoon JH, et al: Intravoxel incoherent motion diffusion-weighted MR imaging for characterization of focal pancreatic lesions. Radiology 2014;270:444-453.

94 Hwang EJ, Lee JM, Yoon JH, et al: Intravoxel incoherent motion diffusion-weighted imaging of pancreatic neuroendocrine tumors: prediction of the histologic grade using pure diffusion coefficient and tumor size. Invest Radiol 2014;49:396-402.

95 Yopp AC, Schwartz LH, Kemeny N, et al: Antiangiogenic therapy for primary liver cancer: correlation of changes in dynamic contrastenhanced magnetic resonance imaging with tissue hypoxia markers and clinical response. Ann Surg Oncol 2011;18:2192-2199.

96 Ng CS, Raunig DL, Jackson EF, et al: Reproducibility of perfusion parameters in dynamic contrast-enhanced MRI of lung and liver tumors: effect on estimates of patient sample size in clinical trials and on individual patient responses. AJR Am J Roentgenol 2010;194: W134-W140.

97 Armbruster M, Sourbron S, Haug A, et al: Evaluation of neuroendocrine liver metastases: a comparison of dynamic contrast-enhanced magnetic resonance imaging and positron emission tomography/computed tomography. Invest Radiol 2014;49:7-14.

MiyazakiK, Orton MR, Davidson RL, etal:Neuroendocrine tumor liver metastases: use of dynamic contrast-enhanced MR imaging to monitor and predict radiolabeled octreotide therapy response. Radiology 2012;263:139-148.
$\$ 99$ Bol K, Haeck JC, Groen HC, et al: Can DCEMRI explain the heterogeneity in radiopeptide uptake imaged by SPECT in a pancreatic neuroendocrine tumor model? PLoS One 2013;8:e77076.

100 Ambrosini V, Fani M, Fanti S, et al: Radiopeptide imaging and therapy in Europe. J Nucl Med 2011;52(suppl 2):42S-55S.

101 Ginj M, Zhang H, Waser B, et al: Radiolabeled somatostatin receptor antagonists are preferable to agonists for in vivo peptide receptor targeting of tumors. Proc Natl Acad Sci USA 2006; 103:16436-16441.

102 Wild D, Fani M, Behe M, et al: First clinical evidence that imaging with somatostatin receptor antagonists is feasible. J Nucl Med 2011;52:1412-1417.

103 Cescato R, Waser B, Fani M, et al: Evaluation of ${ }^{177} \mathrm{Lu}$-DOTA-sst2 antagonist versus ${ }^{177} \mathrm{Lu}$ DOTA-sst2 agonist binding in human cancers in vitro. J Nucl Med 2011;52:1886-1890.

104 Wild D, Macke H, Christ E, et al: Glucagonlike peptide 1-receptor scans to localize occult insulinomas. N Engl J Med 2008;359: 766-768.

105 Wild D, Christ E, Caplin ME, et al: Glucagon-like peptide-1 versus somatostatin receptor targeting reveals 2 distinct forms of malignant insulinomas. J Nucl Med 2011; 52:1073-1078.

106 Selvaraju RK, Velikyan I, Johansson L, et al: In vivo imaging of the glucagonlike peptide 1 receptor in the pancreas with ${ }^{68} \mathrm{Ga}$-labeled DO3A-exendin-4. J Nucl Med 2013;54: 1458-1463.

107 Eriksson O, Velikyan I, Selvaraju RK, et al: Detection of metastatic insulinoma by positron emission tomography with $\left[{ }^{68} \mathrm{Ga}\right]$ exendin-4-a case report. J Clin Endocrinol Metab 2014;99:1519-1524.

108 Nock BA, Maina T, Krenning EP, et al: 'To serve and protect': enzyme inhibitors as radiopeptide escorts promote tumor targeting. J Nucl Med 2014;55:121-127.

109 van Asselt SJ, Oosting SF, Brouwers AH, et al: Everolimus reduces ${ }^{89} \mathrm{Zr}$-bevacizumab tumor uptake in patients with neuroendocrine tumors. J Nucl Med 2014;1:1.

110 Modlin IM, Gustafsson BI, Pavel M, et al: A nomogram to assess small-intestinal neuroendocrine tumor ('carcinoid') survival. Neuroendocrinology 2010;92:143-157.

111 Partelli S, Gaujoux S, Boninsegna L, et al: Pattern and clinical predictors of lymph node involvement in nonfunctioning pancreatic neuroendocrine tumors (NF-PanNETs). JAMA Surg 2013;148:932-939.

112 Liu Y, Sadowski SM, Weisbrod AB, et al: Patient specific tumor growth prediction using multimodal images. Med Image Anal 2014; 18:555-566.

113 Giandomenico V, Modlin IM, Ponten F, et al: Improving the diagnosis and management of neuroendocrine tumors: utilizing new advances in biomarker and molecular imaging science. Neuroendocrinology 2013;28:28. 
114 Gibril F, Reynolds JC, Doppman JL, et al: Somatostatin receptor scintigraphy: its sensitivity compared with that of other imaging methods in detecting primary and metastatic gastrinomas: a prospective study. Ann Intern Med 1996;125:26-34.

115 Krenning EP, Kwekkeboom DJ, Oei HY, de Jong RJ, Dop FJ, Reubi JC, Lamberts SW: Somatostatin-receptor scintigraphy in gastroenteropancreatic tumors. An overview of European results. Ann NY Acad Sci 1994; 733:416-424.

116 Hayashi D, Tkacz JN, Hammond S, et al: Gastroenteropancreatic neuroendocrine tumors: multimodality imaging features with pathological correlation. Jpn J Radiol 2011; 29:85-91.

117 Chiti A, Fanti S, Savelli G, Romeo A, Bellanova B, Rodari $M$, van Graafeiland BJ, Monetti N, Bombardieri E: Comparison of somatostatin receptor imaging, computed tomography and ultrasound in the clinical management of neuroendocrine gastro-entero-pancreatic tumours. Eur J Nucl Med 1998;25:1396-1403.
118 Kwekkeboom DJ, Krenning EP, Bakker WH, Oei HY, Kooij PP, Lamberts SW: Somatostatin analogue scintigraphy in carcinoid tumours. Eur J Nucl Med 1993;20:283292.

119 Kälkner KM, Janson ET, Nilsson S, Carlsson S, Oberg K, Westlin JE: Somatostatin receptor scintigraphy in patients with carcinoid tumors: comparison between radioligand uptake and tumor markers. Cancer Res 1995;55:5801S-5804S.

120 Gustafsson BI, Kidd M, Modlin IM: Neuroendocrine tumors of the diffuse neuroendocrine system. Curr Opin Oncol 2008;20:112.

121 Modlin IM, Kidd M, Latich I, et al: Current status of gastrointestinal carcinoids. Gastroenterology 2005;128:1717-1751.
122 Krenning EP, Bakker WH, Kooij PP, Breeman WA, Oei HY, de Jong M, Reubi JC, Visser TJ, Bruns C, Kwekkeboom DJ, et al: Somatostatin receptor scintigraphy with indium-111-DTPA-D-Phe-1-octreotide in man: metabolism, dosimetry and comparison with iodine-123-Tyr-3-octreotide. J Nucl Med 1992;33:652-658.

123 Phan AT, Oberg K, Choi J, Harrison LH Jr, Hassan MM, Strosberg JR, Krenning EP, Kocha W, Woltering EA, Maples WJ; North American Neuroendocrine Tumor Society (NANETS): NANETS consensus guideline for the diagnosis and management of neuroendocrine tumors: well-differentiated neuroendocrine tumors of the thorax (includes lung and thymus). Pancreas 2010;39:784-798.

124 Kayani I, Conry BG, Groves AM, et al: A comparison of ${ }^{68} \mathrm{Ga}$-DOTATATE and ${ }^{18} \mathrm{~F}$ FDG PET/CT in pulmonary neuroendocrine tumors. J Nucl Med 2009;50:1927-1932.

125 Ambrosini V, Campana D, Nanni C, et al: Is ${ }^{68} \mathrm{Ga}$-DOTA-NOC PET/CT indicated in patients with clinical, biochemical or radiological suspicion of neuroendocrine tumour? Eur J Nucl Med Mol Imaging 2012;39:1278-1283. 